\title{
Kajian Konsep Lund dan Konsep Rosner untuk Tatalaksana Cedera Otak Traumatik Berat
}

\author{
Fitri Sepviyanti $S^{*}$, Iwan Abdul Rachman**), Sri Rahardjo***) \\ ${ }^{*}$ Departemen Anestesiologi dan Terapi Intensif Henan Provincial People's Hospital International Center \\ for Neurosurgery Zhengzhou University-China, ${ }^{* *}$ Departemen Anestesiologi dan Terapi Intensif Fakultas \\ Kedokteran Universitas Padjadjaran-RSUP Dr. Hasan Sadikin Bandung, ${ }^{* * *}$ Departemen Anestesiologi dan Terapi \\ Intensif Fakultas Kedokteran Universitas Gadjah Mada-RSUP Dr. Sardjito Yogyakarta
}

\begin{abstract}
Abstrak
Tatalaksana pasien dengan cedera otak traumatik (COT) berat mengalami perubahan berkesinambungan selama 30 tahun terakhir. Tatalaksana yang diarahkan di unit perawatan intensif (intensive care unit/ICU) mengacu pada tatalaksana klinis sebagai titik akhir terapi utama, bertujuan untuk mempertahankan variabel fisiologis tertentu secara ketat dalam rentang target yang telah ditentukan. Satu alternatif terhadap terapi konvensional ini adalah konsep Lund yang mengutamakan penurunan tekanan mikrovaskular. Konsep Lund termasuk suatu strategi target volume untuk mengendalikan tekanan intrakranial, berasal dari Universitas Lund Swedia, lebih dari 27 tahun yang lalu dan tetap masih kontroversi sampai saat ini. Sejak tahun 1996, American Brain Trauma Foundation dan European Brain Injury Consortium, yang mengacu pada konsep Rosner, telah menerbitkan dan memperbarui panduan untuk tatalaksana cedera otak traumatik. Para ahli sangat menyadari adanya patologi intrakranial multifaktorial yang terlihat pada pasien COT berat dan kompleksitas mekanisme cedera otak sekunder setelah trauma primer, akan menemukan bahwa revisi ini sulit untuk dipahami. Hubungan antara peningkatan tekanan intrakranial (TIK) dan hasil luaran klinis yang lebih buruk sudah terbukti. Menyederhanakan fisiologi otak setelah COT berat ke strategi tatalaksana pasien bedasarkan ambang batas adalah berkaitan erat dengan hubungan interaksi komplek antara: peningkatan TIK, aliran darah otak, dan metabolisme otak.
\end{abstract}

Kata kunci: cedera otak traumatik berat, konsep Lund, konsep Rosner, fisiologi otak

JNI 2020, 9 (2): 126-40

\section{Review of Lund Concept and Rosner Concept for Therapy of Severe Traumatic Brain Injury}

\begin{abstract}
The management of patients with severe traumatic brain injury (TBI) has undergone continuous changes over the past 30 years. Management directed at the intensive care unit (ICU) refers to clinical management as the main end point of therapy, aiming to maintain certain physiological variables strictly within a predetermined target range. One alternative to this conventional therapy is the Lund concept which prioritizes the reduction of microvascular pressure. The concept of Lund includes a volume target strategy for controlling intracranial pressure, from Lund University in Sweden, more than 27 years ago and remains controversial to date. Since 1996, the American Brain Trauma Foundation and the European Brain Injury Consortium, which refers to the Rosner concept, have published and updated guidelines for the management of traumatic brain injury. Experts are well aware of the multifactorial intracranial pathology seen in severe TBI patients and the complexity of the mechanism of secondary brain injury after primary trauma will find that this revision is difficult to understand. The relationship between increased intracranial pressure (ICP) and worse clinical outcome has been proven. Simplifying the physiology of the brain after severe TBI to the patient's management strategy based on the threshold is closely related to the relationship between complex interactions: increased ICP, cerebral blood flow (CBF), and brain metabolism.
\end{abstract}

Key words: severe traumatic brain injury, Lund concept, Rosner concept, brain physiology

JNI 2020, 9 (2): 126-40

This article is licensed under a

Creative Commons Attribution-NonCommercial-ShareAlike 4.0 International License.

CFitri Sepviyanti, Iwan Abdul R, Sri rahardjo (2020)

under the CC-BY-NC-SA license 


\section{Pendahuluan}

Cedera otak traumatik (COT) adalah penyebab utama kematian pada penduduk berusia antara 15 dan 45 tahun di Amerika Serikat, Eropa dan di sebagian besar negara maju serta berkembang lainnya. Pasien yang tidak meninggal karena cedera, mereka sering tetap cacat permanen, menimbulkan beban ekonomi dan sosial yang tinggi. ${ }^{1}$ Cedera otak traumatik berat merupakan penyebab yang nyata dari morbiditas dan mortalitas. Kejadian COT di negara berkembang diperkirakan 200 per 100.000 penduduk yang beresiko per tahun. Sejarahnya, Glasgow Coma Scale (GCS) telah secara luas digunakan untuk mengklasifikasi beratnya COT. Pasien yang masuk ke RS dengan GCS antara 3 dan 8 diperkirakan mengalami COT berat dan diperkirakan 10-15\% pasien yang masuk ke RS dengan COT berat. Sejak tahun 1990-an telah diketahui bahwa kebanyakan kerusakan neuron setelah COT tidak terjadi saat traumanya tetapi beberapa jam atau hari kemudian setelah trauma. Satu perbedaan dibuat antara cedera otak primer dan cedera otak sekunder. ${ }^{2}$ Cedera otak sekunder mempunyai arti penting karena berkembang saat pasien sedang diterapi. Oleh karena itu, terapi untuk mencegah atau mengurangi cedera otak sekunder merupakan hal yang sangat penting. ${ }^{2}$

Iskemia serebral merupakan konsekuensi yang paling penting dari cedera otak sekunder. Masalah patofisiologik utama adalah gangguan aliran darah otak pascatrauma akibat peningkatan intracranial pressure/ICP dan pembentukan edema otak. ${ }^{2}$ Pendekatan konvensional dalam pencegahan cedera otak sekunder adalah ICPtarget yaitu terapi dengan target ICP, seperti elevasi kepala, sedasi, pemberian obat pelumpuh otot, drainase cerebrospinal fluid/CSF, terapi hiperosmoler, hiperventilasi, barbiturat coma seperti yang disebutkan sebagai first-tier dan second-tier therapy. ${ }^{2}$ Pendekatan yang sama, adalah target CPP (cerebral perfusion pressure/CPP) yaitu target tekanan perfusi otak, mengutamakan peranan CPP, yaitu perbedaan tekanan arteri rerata dengan ICP. Teknik ini berbeda dengan ICP-target dimana dilakukan posisi kepala datar, hindari sedasi, hiperventilasi dan barbiturat coma, tapi sama dalam pemberian osmoterapi, drainase CSF dan pemberian obat pelumpuh otot. $^{2}$ Berlawanan dengan konsep pendekatan terapi secara konvensional, konsep Lund mengutamakan pengurangan tekanan mikrovaskular untuk mengurangi pembentukan edema serebral. Edema serebral terjadi disebabkan karena bocornya molekul besar seperti albumin dari pembuluh darah melalui kerusakan sawar darah otak (blood brain barrrier/BBB). Perpindahan cairan serebrospinal (cerebrospinal fluid/CSF) ke dalam otak setelah albumin secara osmosis. Edema vasogenik ini menyebabkan penekanan dan kerusakan jaringan otak. Sasaran dari pendekatan konsep Lund adalah memelihara tekanan koloid osmotik yang normal (dengan infus albumin dan koreksi anemia), untuk mengurangi tekanan hidrostatik kapiler (dengan pengendalian medikal terhadap tekanan darah) dan untuk mengurangi volume darah otak (cerebral blood volume/CBV) dengan vasokonstriksi. ${ }^{2}$

Mempertahankan tekanan osmotik koloid normal akan menahan air intrakapiler, sehingga akan mengurangi transudasi dan pembentukan edema interstitial. Mempertahankan tekanan arteri rerata (Mean arterial pressure/MAP) dalam rentang normal rendah, dan akibatnya akan mempertahankan tekanan hidrostatik kapiler yang rendah, akan memfasilitasi terjadinya efek ini. Untuk mendukung konsep ini, adalah penting untuk tidak melakukan setiap prosedur yang bekerja berlawanan dengan prinsip tersebut. Suatu penurunan pembentukan edema otak akan memperbaiki aliran darah otak (cerebral blood flow/CBF) dan mengurangi frekuensi, lama dan besarnya episode iskemia, dan sekuele cedera otak sekunder. Konsekuensinya, akan menyebabkan hasil luaran lebih baik (misalnya mengurangi mortalitas dan disabilitas jangka panjang). ${ }^{2}$ Sasaran utama pengelolaan pasien mengacu pada strategi terapeutik yang memiliki tujuan untuk mempertahankan beberapa variabel fisiologis secara ketat dalam rentang target yang telah ditentukan. Sejak tahun 1996, American Brain Trauma Foundation dan European Brain Injury Consortium telah menerbitkan dan memperbarui panduan untuk manajemen cedera otak traumatik. Panduan-panduan ini telah memberikan dasar 
yang penting untuk penerimaan yang luas dari manajemen yang diarahkan pada tujuan di ICU bedah saraf, meskipun rekomendasi yang diberikan sebagian besar didasarkan studi observasional, pemahaman fisiologis, penelitian hasil laboratorium, dan pendapat para ahli.. ${ }^{1,6}$ Saat ini, sebagian besar protokol terapi menentukan nilai target eksplisit untuk pengelolaan ICP, CBF, suhu dan beberapa variabel lainnya. Jika suatu variabel tidak dapat dipertahankan dalam kisaran yang diinginkan, algoritma penanganan 6 digunakan untuk memilih intervensi selanjutnya yang akan dilakukan, hal ini tergantung dari karakteristik pasien. Dengan asumsi bahwa operasi merupakan pilihan yang patut dipertimbangkan, pilihan perawatan utama di ICU berupa: terapi hipertensi arteri yang disengaja, terapi hiperosmolar, hiperventilasi dan terapi penekanan metabolik otak..$^{3-6}$ Sampai saat ini penelitian-penelitian yang dilakukan tidak dapat menunjukkan bahwa hasil luaran dari cedera otak traumatik dapat ditingkatkan dengan menggunakan algoritma manajemen yang terfokus pada tujuan pengelolaan pasien secara ketat di ICU, juga tidak ada bukti kemanjuran untuk setiap intervensi fisiologis tertentu. Hal ini disebabkan karena secara uji coba masih kurang. Sebagai akibatnya, banyak menimbulkan kontroversi tentang pengelolaan optimal pasien cedera kepala traumatik berat, sebagaimana dibuktikan oleh sebagian besar rumah sakit pusat bedah saraf dalam perawatan rutin pasien di seluruh dunia. ${ }^{3-6}$

\section{Perubahan pada Hemodinamik Serebral}

Ada perubahan berurutan dalam fisiologi serebrovaskular setelah trauma kepala yang terkait erat dengan proses cedera otak primer dan sekunder yang dijelaskan di atas. Pada banyak pasien, CBF menunjukkan pola triphasic (Gambar 2). ${ }^{3-8}$ Awal setelah cedera kepala (dalam waktu 12 jam), CBF global biasanya berkurang, kadangkadang ke tingkat iskemik. Antara 12 dan 24 jam pasca cedera CBF meningkat, dan otak mungkin menunjukkan aliran supernormal. Sementara beberapa penulis menyebut fenomena ini sebagai hiperemia, tidak adanya pengurangan ekstraksi oksigen otak pada banyak pasien menunjukkan bahwa metabolisme dan aliran darah tetap digabungkan, dan label yang lebih tepat adalah hiper perfusi. CBF mulai
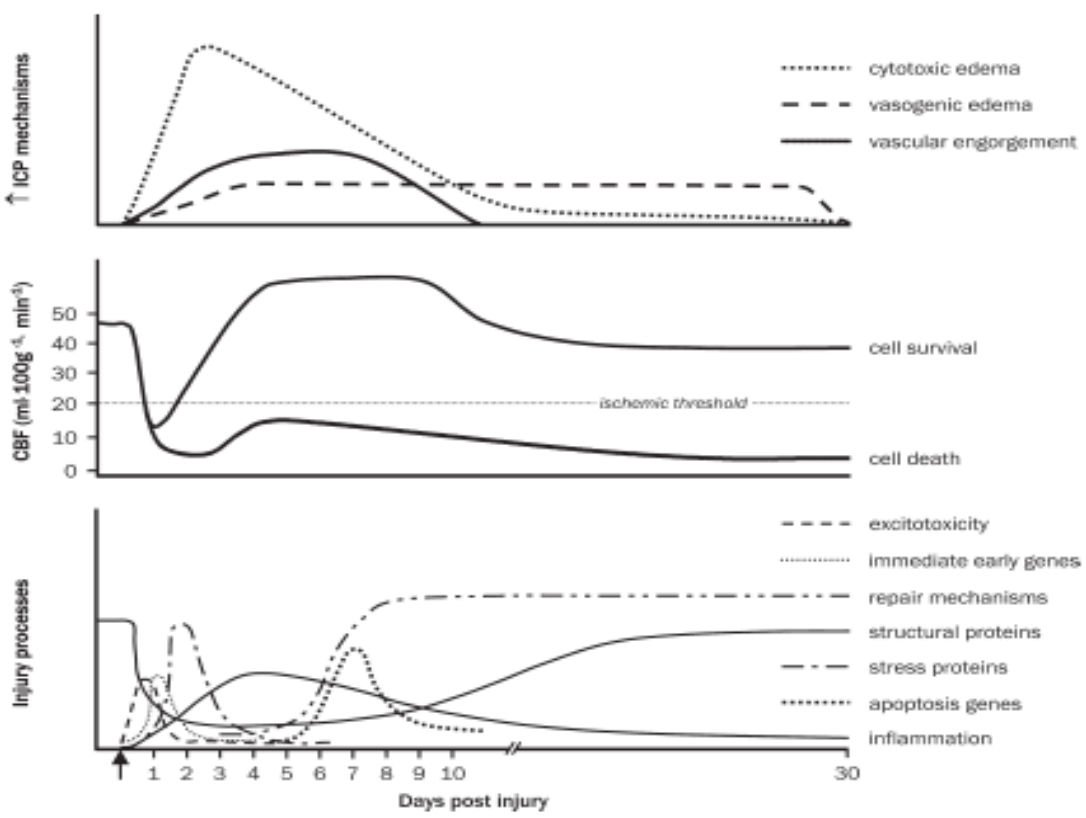

Gambar 1. Aktivasi berurutan dari proses cedera (bawah), respon serebrovaskular (tengah) dan mekanisme yang terlibat dalam pembengkakan otak (atas) setelah

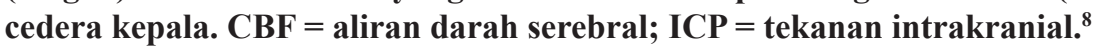

Di kutip dari Menon DK. Br Med Bull 1999 
berkurang beberapa hari setelah cedera kepala. Pada beberapa pasien, terutama jika terdapat darah subarachnoid, penurunan CBF ini terkait dengan perubahan kecepatan aliran pembuluh darah yang besar pada ultrasound Doppler transkranial, yang menunjukkan vasospasme. ${ }^{3-8}$ Pengetahuantentang perkembanganhemodinamik serebral mungkin berguna untuk memahami mekanisme yang paling mungkin terlibat dalam pengembangan hipertensi intrakranial setelah COT (Gambar 1). Hipertensi intrakranial terjadi akibat peningkatan volume cairan serebrospinal, volume sel (edema sitotoksik), volume cairan interstisial (edema vasogenik), volume darah otak (pembesaran vaskular), atau kombinasi faktor-faktor ini. Terlepas dari lesi massa fokal, peningkatan ICP segera setelah COT terutama merupakan konsekuensi edema cytotoxic.
Peningkatan $\mathrm{CBF}$ dan volume darah otak dari hari kedua dan seterusnya membuat pembengkakan vaskular merupakan kontributor penting untuk hipertensi intrakranial. Pada hari kedua sampai dengan kelima, tampak terjadi kebocoran kapiler, dan edema vasogenik kemudian berkontribusi terhadap pembengkakan otak. Pola-pola ini tidak tetap dan dapat diprediksi pasti terjadi sesuai gambar di atas, disebabkan karena proses yang berbeda dapat terjadi bersamaan dalam satu pasien pada waktu tertentu. ${ }^{3-8}$

\section{Tatalaksana Cedera Otak Traumatik Berat}

Tatalaksana COT berat sudah lama diminati orang. Temuan arkeologi tengkorak dengan tanda-tanda trephination telah ditemukan. Hippocrates dan Galen menjelaskan indikasi untuk trephination karena patah tulang tengkorak. ${ }^{8}$ Tatalaksana yang

Tabel 1. Perbandingan Konsep Pendekatan Tatalaksana di ICU untuk Pasien dengan COT. ${ }^{9}$

\begin{tabular}{|c|c|c|c|}
\hline & Target ICP & Target CPP & Target volume \\
\hline Tujuan patofisiologi & $\begin{array}{l}\text { hiperemia/hiperperfusi } \\
\text { pelebaran pembuluh } \\
\text { darah otak }\end{array}$ & $\begin{array}{l}\text { Hiperpefusi pada } \\
\text { cytotoxic edema }\end{array}$ & $\begin{array}{l}\text { Hyperemia vasogenic } \\
\text { edema }\end{array}$ \\
\hline Asumsi & $\begin{array}{l}\text { Reaktivitas } \\
\mathrm{CO}_{2}+\text { memelihara flow } \\
\text { metabolism coupling }\end{array}$ & $\begin{array}{l}\text { Memelihara } \\
\text { autoregulasi otak } \\
\text { (mungkin bergeser ke } \\
\text { kanan) }\end{array}$ & $\begin{array}{l}\text { Penurunan autoregulasi } \\
\text { otak: terganggunya } \\
\text { BBB }\end{array}$ \\
\hline Target dari ICP & $<20 \mathrm{mmHg}$ & Tidak dipertimbangkan & $<25 \mathrm{mmHg}$ \\
\hline Target dari CPP & Tidak dipertimbangkan & »70-80 mmHg & $\gg 50 \mathrm{mmHg}$ \\
\hline Terapi cairan & $\begin{array}{l}\text { Kristaloid: menjaga } \\
\text { normovolemia }\end{array}$ & $\begin{array}{l}\text { Kristaloid+koloid; } \\
\text { supaya hypervolemia }\end{array}$ & $\begin{array}{l}\text { Albumin, plasma; } \\
\text { furosemide agar balans } \\
\text { cairan negatif }\end{array}$ \\
\hline Obat-obatan vasoaktif & & Catecholamines & Dihydroergotamine \\
\hline Hipertensi arteri & $\begin{array}{l}\text { Tidak; labetolol jika } \\
\text { TDS > } 160 \text { mmHg }\end{array}$ & $\begin{array}{l}\text { Ya; obat-obatan } \\
\text { vasoaktif untuk } \\
\text { meningkatkan TD }\end{array}$ & $\begin{array}{l}\text { Tidak; metoprolol } \\
\text { dan clonidine untuk } \\
\text { menurunkan TD }\end{array}$ \\
\hline Posisi kepala & Elevasi kepala $15^{0}-30^{0}$ & Datar & Datar \\
\hline CSF drainage & Ya & Ya & Tidak \\
\hline Osmotherapy & $\begin{array}{l}\text { Ya; manitol atau } \\
\text { hypertonic saline }\end{array}$ & $\begin{array}{l}\text { Ya; manitol atau hyper- } \\
\text { tonic saline }\end{array}$ & $\begin{array}{l}\text { Tidak; memelihara } \\
\text { tekanan onkotik koloid }\end{array}$ \\
\hline Sedasi & $\begin{array}{l}\text { Ya;benzodiazepin, pro- } \\
\text { pofol dan/atau morfin }\end{array}$ & Tidak & $\begin{array}{l}\text { Ya; thiopental dosis } \\
\text { rendah, benzodiazepin, } \\
\text { fentanyl dan clonidine }\end{array}$ \\
\hline Metabolic suppression & $\begin{array}{l}\text { Ya; high dose hynoptics } \\
\text { dan/atau hipotermia }\end{array}$ & Tidak & Tidak \\
\hline Hiperventilasi & $\mathrm{Ya}$ & Tidak & Tidak \\
\hline
\end{tabular}

Dikutip dari: Dizdarevic K, Hamdan A, Omerhodzic I, Kominlija-Smajic E, 2012 
diarahkan di ICU mengacu pada pengelolaan klinis sebagai titik akhir terapi utama, bertujuan untuk mempertahankan variabel fisiologis tertentu secara ketat dalam rentang target yang telah ditentukan. Jika suatu variabel tidak dapat dipertahankan dalam rentang target itu, algoritma penanganan step-up digunakan untuk memilih intervensi yang tepat. Dalam pedoman ini, adalah mungkin untuk membedakan beberapa pendekatan yang berbeda secara konseptual (Tabel 1). ${ }^{1-8}$ Ini termasuk strategi terapeutik yang memiliki fokus utama pada (1) pengurangan volume darah otak dan ICP, (2) augmentasi CPP dan $\mathrm{CBF}$, atau (3) pengurangan pertukaran cairan dari kapiler ke otak. ${ }^{1-8}$ Penting untuk diketahui bahwa tujuan tatalaksana dalam praktek klinis mungkin lebih beragam daripada yang dapat dicerminkan oleh pendekatan konseptual ini. Selain itu, tergantung pada variabel fisiologis yang dipantau, terapi dapat bervariasi antara pasien atau pada satu pasien dari waktu ke waktu. Ada beberapa standar perawatan yang diterima secara umum untuk pasien COT yang tidak dipertimbangkan dalam pendekatan konseptual ini. Misalnya, secara umum disepakati bahwa pasien dengan GCS $\leq 8$ memerlukan intubasi untuk perlindungan saluran napas, dan pasien seperti itu harus menerima ventilasi mekanis untuk memastikan oksigenasi yang adekuat dan kontrol $\mathrm{PaCO}_{2}$, dan kadar glukosa mungkin harus dipertahankan dalam kisaran normal $(\approx 4-7$ $\mathrm{mmol} / \mathrm{L}$ ). Namun, pendekatan konseptual (Tabel 1) dapat berguna, karena berhubungan dengan terapi perawatan intensif untuk tujuan fisiologis tertentu dan menjelaskan asumsi yang mendasari mengenai status reaktivitas serebrovaskular serta fungsi penghalang otak darah untuk setiap intervensi. ${ }^{1,3-8}$

\section{Tatalaksana dengan target ICP}

Pendekatan konvensional untuk pengelolaan cedera kepala berat telah difokuskan pada evakuasi bedah awal lesi massa intrakranial dan tatalaksana yang teliti dari peningkatan hipertensi intrakranial, menggunakan pendekatan bertahap. Hal ini berarti bahwa terapi ditambahkan dalam urutan yang mencerminkan risiko komplikasi yang terkait dengan intervensi (misalnya: dimulai dengan sedasi atau drainase cairan serebrospinal, dan diakhiri dengan barbiturat koma). Untuk tujuan diskusi konseptual, kami hanya akan mempertimbangkan intervensi yang khusus untuk pendekatan yang ditargetkan ICP. Variable yang termasuk penggunaan hipokapnia yang disengaja dan terapi supresi metabolik otak. Kedua tindakan ini terutama ditujukan pada pengurangan volume darah otak dan didasarkan pada asumsi bahwa autoregulasi metabolik sebagian besar dipertahankan setelah cedera. Penggunaan terapi osmotik akan dibahas dalam kaitannya dengan pendekatan yang ditargetkan CPP. ${ }^{1,3-8}$

Brain Trauma Foundation (BTF) baru-baru ini memperbarui pedoman protokol terapi untuk pengelolaan pasien rawat inap dengan cedera otak traumatik akut. Dibandingkan dengan pedoman 2007 sebelumnya, beberapa rekomendasi telah diubah untuk memenuhi standar kualitas. Mengingat penelitian yang mendasari bersifat deskritif, termasuk dalam pedoman sebelumnya, pedoman yang diperbarui tidak lagi memberikan rekomendasi untuk indikasi khusus untuk pemantauan ICP. Berdasarkan bukti kualitas rendah (tingkat IIB), pemantauan ICP untuk mengurangi tingkat kematian di rumah sakit dan 2 minggu pascacedera masih disarankan. Salah satu perubahan yang lebih luar biasa dalam pedoman 2016 adalah ambang batas yang lebih tinggi untuk pengelolaan tekanan intrakranial: dari 20 hingga $22 \mathrm{mmHg}$. ${ }^{1,3-8}$

Para ahli sangat menyadari adanya patologi intrakranial multifaktorial yang terlihat pada pasien COT berat dan kompleksitas mekanisme cedera otak sekunder setelah trauma primer akan menemukan bahwa revisi ini sulit untuk dipahami. Hubungan antara peningkatan ICP dan hasil luaran klinis yang lebih buruk sudah terbukti. Pengelolaan hanya berdasarkan hipertensi intrakranial pada semua pasien tidak masuk akal. ${ }^{1,3-8}$ Rekomendasi tingkat IIB baru dalam pengelolaan ICP pada ambang $22 \mathrm{mmHg}$ didasarkan pada penelitian retrospektif di salah satu pusat terhadap 459 pasien COT berat, dirawat selama 12 tahun. Penelitian ini bertujuan untuk mengidentifikasi ambang batas untuk ICP dan 
variabel pemantauan otak terkait lainnya yang menunjukkan hubungan statistik tertinggi dengan hasil. ${ }^{1,3-8}$ Keputusan BTF untuk merubah ambang ICP atas dasar penelitian ini menjadi kontroversial di kalangan para ahli. Pertama, dalam penelitian ini, ICP telah ditangani, sehingga hubungan yang ditemukan mungkin menunjukkan kegagalan terapi daripada ambang batas pengelolaan. Kedua, ICP di seluruh rumah sakit setiap pasien yang diambil berdasarkan rerata.

Dari sudut pandang konseptual, ini sangat berbeda dibandingkan dengan situasi klinis dengan variasi nilai ICP yang tergantung waktu di atas atau di bawah ambang batas yang diberikan, selain itu, karena ICP adalah variabel fisiologis berkelanjutan, penting untuk menggunakan variabel yang tepat dan data akurat, sehingga diperlukan tindakan berulang pada pasien. Ketiga, "ambang" yang teridentifikasi diterapkan pada keseluruhan kohort, terutama laki-laki $(77,5 \%)$ dan pasien muda (rata-rata 34 tahun). Dalam subkelompok pasien wanita atau lanjut usia, "ambang" yang berbeda dari $18 \mathrm{mmHg}$ telah diidentifikasi, sudah menunjukkan bahwa "satu-ukuran-cocok-semua rekomendasi" perlu dipertanyakan. Keempat, perubahan $2 \mathrm{mmHg}$ dapat terjadi kesalahan pengukuran ICP. Hal-hal ini mengakibatkan kebinggungan para ahli ketika harus menentukan terapi pada pasien dengan ICP $22 \mathrm{mmHg}$. Haruskah kita menerapkan pengelolaan agresif ketika ICP $23 \mathrm{mmHg}$, tetapi tidak ketika $21 \mathrm{mmHg}$ ? Mengetahui bahwa buktinya rendah untuk sebagian besar, jika tidak semua intervensi terapeutik untuk pengelolaan pasien dengan ICP yang meningkat, tidak jelas tingkat intensitas terapi ambang batas $22 \mathrm{mmHg}$. ${ }^{1,3-8}$

Beberapa penelitian menunjukkan bahwa bahkan episode ICP $<20$ (atau 22) $\mathrm{mmHg}$ bisa relevan, tergantung pada durasi kelainan ini. Hal ini menyiratkan bahwa pemahaman yang terlalu sederhana tentang ambang patologi (misalnya, ICP $>22 \mathrm{mmHg}$ ) mengarah pada kesalahpahaman saat ini bahwa "normalitas" (misalnya ICP $<22$ $\mathrm{mmHg}$ ) menjamin tidak adanya proses patologis. Hal ini menunjukkan bahwa "ICP normal" tidak selalu menjamin perfusi serebral dan pengiriman oksigen yang cukup. Sebagai contoh, perubahan
ICP yang bergantung pada CPP bersifat dinamis, oleh karena itu memerlukan fleksibilitas dan pemantauan ketat terapeutik, sebuah fakta yang sering diabaikan. ${ }^{1,3-8}$

\section{Hiperventilasi}

Hiperventilasi dengan cepat mengurangi volume darah intrakranial dan vasokontriksi terjadi tergantung $\mathrm{pH}$ resistensi pembuluhpembuluh kapiler. Hal ini disebabkan karena secara konseptual, reaktivitas karbondioksida serebrovaskular dipertahankan lebih banyak jumlahnya dalam jaringan otak yang relatif sehat dibandingkan dengan daerah yang mengalami cedera parah atau zona penumbra. Secara teoritis masih belum jelas, pengurangan aliran darah di daerah yang paling rentan terhadap hipoksi-iskemik. Hiperventilasi berkepanjangan mungkin memiliki nilai yang terbatas, bahkan mungkin berbahaya pada kasus-kasus tertentu. Hal ini disebabkan karena: pertama, pengurangan $\mathrm{CBF}$ dan volume darah selama hipokapnia berkelanjutan hanya sementara (4-6 jam), karena pengurangan kompensasi kadar bikarbonat cairan ekstra seluler untuk pengembalikan kadar $\mathrm{pH}$ tetap normal dari waktu ke waktu. Kedua, ada data yang menunjukkan bahwa hiperventilasi dapat mengurangi CBF global atau regional di bawah ambang iskemik, dan berdampak buruk pada hasil luaran pasien. Dalam hal ini, diperlukan pemantauan terus menerus saturasi oksigen vena jugularis $\left(\mathrm{SjO}_{2}\right)$. Pengurangan $\mathrm{SjO}_{2} \leq 50-55 \%$, atau peningkatan arteri untuk perbedaan vena jugularis dalam kandungan oksigen hingga lebih dari $9 \mathrm{ml} / 100 \mathrm{ml}(4 \mathrm{mmol} / \mathrm{L})$, menunjukkan bahwa aliran darah otak global mungkin tidak memadai dan terapi hiperventilasi harus dihentikan, kembali menjadi normoventilasi. ${ }^{1,3-8}$

\section{Terapi Supresi Metabolik}

Vasokonstriksi serebral yang berlangsung dan pengurangan ICP dapat dicapai sebagai respons terhadap reduksi metabolisme energi serebral, asalkan sambungan (coupling) metabolisme aliran dipertahankan. Infus barbiturat intravena dosis tinggi secara konvensional telah digunakan untuk tujuan ini, tetapi baru-baru ini propofol juga telah dikemukakan. Pengelolaan dengan 
barbiturat dosis tinggi yang berkepanjangan sering dikaitkan dengan komplikasi paru, kardiovaskular dan lainnya, sedangkan infus propofol dosis tinggi memaksakan beban lipid yang signifikan dan tampaknya terkait dengan efek samping dan mortalitas yang berat. Obatobatan penghambat neuromuskular biasanya diperlukan dalam pengelolaan ini, dan mungkin menimbulkan komplikasi tersendri, seperti: kelumpuhan lanjutan setelah penghentian, neuropati penyakit kritis atau miopati dan komplikasi pernapasan atau infeksi. ${ }^{1,3-8}$

\section{Hipotermia}

Hipotermia ringan sampai sedang $\left(31-34^{\circ} \mathrm{C}\right)$ telah digunakan untuk menurunkan ICP, baik sebagai alternatif dan tambahan pada penekanan efek farmakologis kebutuhan metabolik serebral basal. Hipotermia juga telah dilaporkan menumpulkan kaskade proses cedera sekunder setelah cedera kepala. Pada beberapa penelitian observasional yang menggunakan model hewan dan studi klinis awal dari cedera otak traumatik, tetapi hipotermia gagal meningkatkan hasil luaran pasien dalam uji coba terkontrol secara acak yang besar, meskipun itu secara efektif mengurangi hipertensi intrakranial. Hal ini mengakibatkan fokus kini bergeser dari penggunaan hipotermia yang disengaja menuju pencegahan dan pembalikan hipertermia spontan. Berbeda dengan efek metabolik hipotermia, bagaimanapun, pengurangan ICP melalui pembalikan suhu mungkin lebih terkait dengan pemulihan pembuluh darah serebrovaskular normal dan autoregulasi, daripada pengurangan kebutuhan metabolik otak untuk oksigen., ${ }^{1,3-8}$

\section{Tatalaksana dengan Target CPP}

Tatalaksana dengan target CPP diperkenalkan oleh Rosner dkk pada tahun 1995, pedoman ini didasarkan pada konsep fisiologis dari kaskade vasodilator. Menurut hipotesis ini, penurunan CPP baik penurunan tekanan arteri, peningkatan ICP, atau keduanya merangsang pembuluh serebral untuk melebar, dalam upaya untuk mempertahankan aliran darah otak konstan. Hal ini disebabkan karena peningkatan volume darah otak yang menyertai vasodilatasi menurunkan CPP dengan meningkatkan ICP, ini membentuk siklus yang mengarah pada kerusakan lebih lanjut dari CPP. Konsep dengan target CPP mengasumsikan
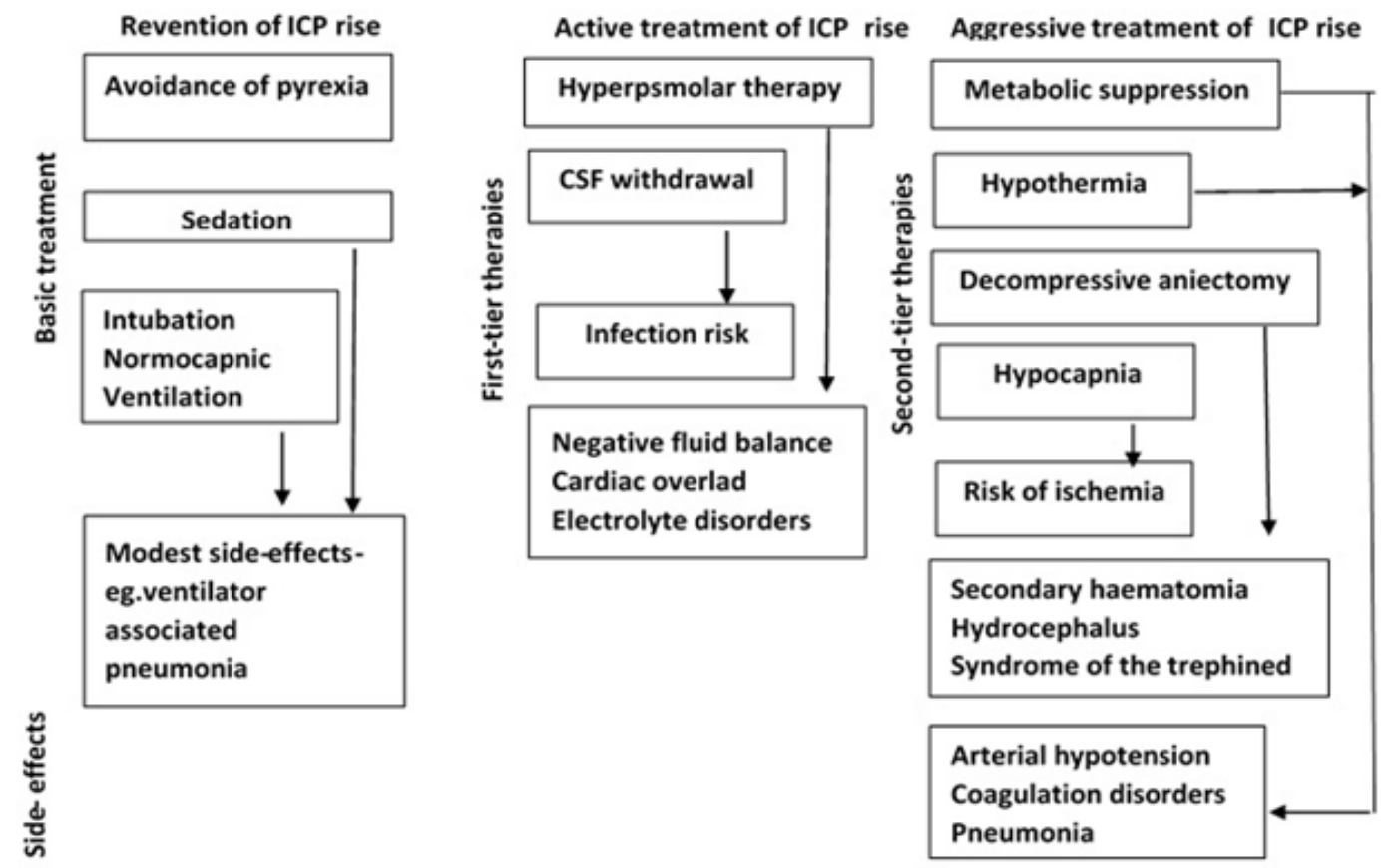

Gambar 2. Komplikasi Tatalaksana dengan Target ICP yang Mungkin Terjadi 
bahwa autoregulasi tekanan dipertahankan pada sebagian besar pasien. Hipotesis lebih lanjut menyatakan bahwa kurva autoregulasi telah bergeser ke kanan pada banyak pasien, membuat otak rentan terhadap tekanan perfusi rendah. CPP secara konseptual harus disimpan di ambang atas tekanan autoregulasi untuk memaksimalkan pengurangan volume darah otak yang dapat diperoleh. Hal ini menyiratkan bahwa tatalaksana dengan target CPP ditetapkan pada tingkat yang lebih tinggi ( $>70-80 \mathrm{~mm} \mathrm{Hg}$ atau lebih) daripada nilai $60 \mathrm{mmHg}$ yang dianggap memberikan perfusi yang lebih memadai bagi sebagian besar pasien..$^{1,3-8}$

CPP dapat ditingkatkan dengan menurunkan posisi kepala sejajar dengan seluruh tubuh, meningkatkan tekanan arteri rata-rata, atau dengan mengurangi ICP. Tindakan untuk menurunkan ICP dengan vasokonstriksi serebral (misalnya, hiperventilasi) tidak sesuai secara logis dalam konsep tatalaksana dengan target CPP. Hal ini disebabkan karena pada konsep ini mengasumsikan bahwa otak beroperasi pada batas bawah autoregulasi dan rentan terhadap iskemia akibat hipoperfusi. Sebaliknya, osmoterapi lebih rasional digunakan untuk mengobati edema sitotoksik yang berhubungan dengan iskemia jaringan. ${ }^{1,3-8}$

\section{Hipertensi Arteri}

Augmentasi tekanan arteri rerata melibatkan ekspansi volume intravena untuk mendapatkan preload jantung yang adekuat dan infus inotropik serta vasopresor yang terus menerus. Pada praktik ini telah dikaitkan dengan peningkatan risiko sindrom gangguan pernapasan dewasa pada pasien cedera kepala traumatik dan mungkin komplikasi jantung. Infus norepinefrin dosis tinggi yang telah lama digunakan untuk mempertahankan hipertensi arteri juga dapat menjadi faktor pemicu untuk pengembangan sindrom infus propofol yang sangat mematikan pada pasienpasien dengan COT. Pada beberapa penelitian menunjukkan bahwa katekolamin tidak memiliki efek langsung pada pembuluh serebral pasien yang sehat, tidak ada data tentang keamanan infus dosis besar obat vasoaktif diberikan pada BBB yang terganggu, dan mungkin katekolamin dapat menyebabkan vasokonstriksi lokal tidak diinginkan di otak yang cedera. ${ }^{1,3-8}$

\section{Osmoterapi}

Manitol intravena secara konvensional telah digunakan untuk terapi hiperosmolar setelah trauma otak. Efek manitol selain sebagai osmotik dan diuretiknya, juga memiliki sifat antioksidan dan aktivitas rheologic. Penurunan viskositas darah setelah infus manitol mungkin berkontribusi terhadap pengurangan ICP dengan merangsang vasokonstriksi serebral autoregulasi. $\mathrm{NaCl}$ hipertonik adalah obat osmotik alternatif yang dapat secara efektif digunakan untuk resusitasi cairan volume kecil pada pasien cedera kepala

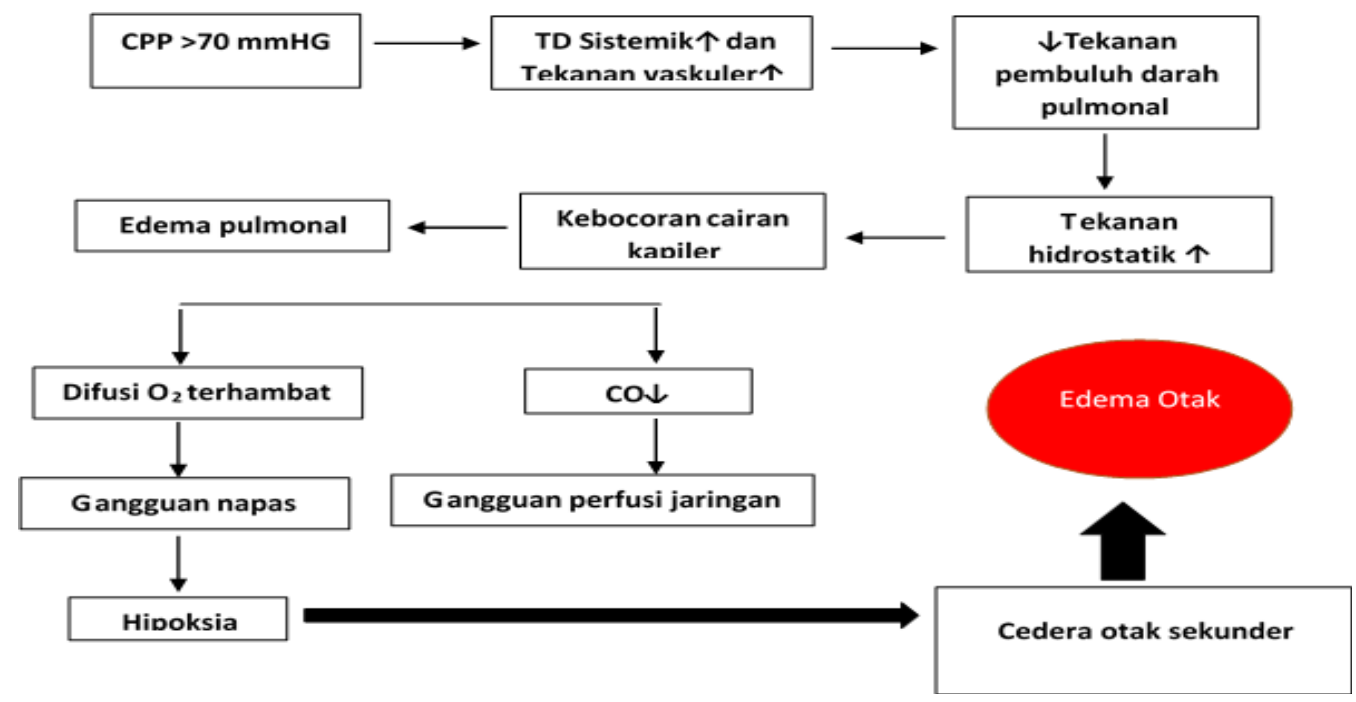

Gambar 3. Skema Komplikasi Patofisologi akibat Tatalaksana Tipertensi Arteri 
dengan trauma sistemik mayor, dan pada kasus hipertensi intrakranial menetap. $\mathrm{NaCl}$ hipertonik memiliki efek osmolar yang berpotensi sedikit lebih besar daripada manitol yang diberikan pada dosis ekimolar (koefisien refleksi darahotak 1,00 untuk $\mathrm{NaCl}$ dibandingkan dengan 0,90 untuk manitol). $\mathrm{NaCl}$ hipertonik juga dapat memperbaiki aliran darah otak regional dengan mendehidrasi endotelium serebrovaskular dan eritrosit.

Stabilisasi membran, modulasi kekebalan dan efek berpotensi menguntungkan lainnya juga telah diklaim. ${ }^{1,3-8}$ Terapi hiperosmolar bergantung pada fungsi keutuhan BBB. Jika maksud dan tujuan pemberian manitol atau $\mathrm{NaCl}$ hipertonik di daerah memar atau perdarahan, obat-obatan osmotik dapat lewat dari darah ke ruang interstitial, di mana mereka mungkin menyebabkan pergeseran osmotik terbalik dan hipertensi intrakranial 'rebound'. Manitol adalah diuretik yang kuat dan pemberiannyayang berulangmenempatkan pasien pada risiko dehidrasi jika keseimbangan cairan tidak dapat dipertahankan. Terapi hiperosmolar juga memiliki potensi toksisitas ginjal, yang mungkin dapat dikurangi jika osmolalitas plasma disimpan di bawah $320 \mathrm{mosm} / \mathrm{L} .^{1,3-8}$

\section{Tatalaksana dengan Target Volume Otak}

Volume-target atau yang dikenal juga sebagai 'Konsep Lund' menekankan pengurangan tekanan mikrovaskular untuk meminimalkan edema di otak. Secara konseptual, pendekatan ini mengasumsikan bahwa autoregulasi tekanan terganggu atau benar-benar dihapuskan (memungkinkan konduksi hidraulik tekanan hidrostatik arteri ke kapiler) dan BBB terbuka untuk zat terlarut kecil (memungkinkan agen osmotik bocor ke ruang interstisial). Tujuan dari strategi ini adalah untuk mempertahankan tekanan onkotik koloid normal, untuk mengurangi tekanan hidrostatik kapiler dengan mengurangi tekanan darah sistemik dan untuk mengurangi volume darah otak dengan vasokonstriksi kapasitansi vena dan resistensi pembuluh kapiler. Pengelolan yang masuk dalam konseptual ini adalah: peningkatan filtrasi cairan transkapiler dihindari, termasuk drainase cairan serebrospinal, barbiturat dosis tinggi, diuretik osmotik, dan CPP tinggi. ${ }^{1,3-8}$ Protokol klinis yang disajikan oleh kelompok dari Lund, Swedia, menggunakan infus dosis rendah tiopental dan dihidroergotamine untuk menyempitkan arteriol dan venula serebral, metoprolol dan clonidine untuk mengurangi tekanan darah, sehingga nilai CPP dipertahankan serendah $50 \mathrm{mmHg}$ pada orang dewasa. Tatalaksana juga menganjurkan eritrosit/sel darah merah, plasma dan transfusi albumin digunakan untuk mempertahankan normovolemia dan mengembalikan tekanan onkotik plasma setelah cedera, kelebihan cairan dihindari dengan menggunakan furosemide dan jumlah cairan kristaloid terbatas. Posisi head-up tidak digunakan karena hanya akan menyebabkan kolaps vena di mana vena bridging melewati dura, menyebabkan volume darah intrakranial tidak berubah. Cerebrospinal fluid drainage dan dekompresi kraniektomi juga tidak secara rutin dilakukan, karena intervensi ini akan menurunkan tekanan jaringan dan mendukung filtrasi cairan kapiler, berpotensi mengakibatkan pergeseran massa otak yang tidak diinginkan. ${ }^{1-8}$

Konsep Lund untuk terapi COT berat dilakukan dengan pendekatan teori terutama berdasarkan pada prinsip fisiologik dan patofisiologik volume otak dan pengaturan perfusi otak. Konsep ini bertujuan untuk menetralkan peningkatan ICP atau untuk menurunkan peningkatan ICP yang telah terjadi setelah COT berat seraya memperbaiki perfusi dalam dan sekeliling jaringan otak yang mengalami kontusio. Teknik ini dapat dipertimbangkan sebagai pendekatan ICP dan pendekatan perfusi. Komponen utama konsep Lund telah didukung oleh penelitian ekperimental dan penelitian klinis. ${ }^{10-20}$ Sampai sejauh ini, tidak ada pedoman terapi COT yang telah diuji dalam penelitian RCT besar dan dari titik pandang ini bukti klinis high-level untuk guideline COT sangat terbatas. Karena itu terapi spesifik harus berdasarkan pada masukan lebih kecilnya penelitian tentang outcome klinis termasuk penelitian metaanalisis, penelitian eksperimental, dan prinsip fisiologi dasar. ${ }^{10-20}$ Walaupun pedoman yang berbeda, maka aspek yang mendasarinya akan beda pula, pedoman dari Brain Trauma Foundation telah semakin dekat ke konsep Lund dalam 10 tahun yang lalu, 
misalnya pertimbangan $\mathrm{CPP}$ dan penggunaan vasopresor. Berlawanan dengan BTF guideline, yang mana terapi peningkatan ICP dimulai bila ICP lebih dari $20 \mathrm{mmHg}$, konsep Lund merekomendasikan bahwa terapi harus sesegera mungkin begitu pasien masuk ke rumahsakit, dalam usaha untuk menetralkan berkembangnya edema otak dan menjamin perfusi yang optimal. Sebagai pengetahuan, tidak jelas efek samping dari konsep Lund, yang mana dapat diberikan segera pada semua pasien tanpa memandang beratnya cedera dan beratnya derajat gangguan autoregulasi. Konsep Lund tidak berubah sejak diperkenalkan, kecuali bahwa dihidroergotamin tidak digunakan lagi. Dihidroergotamin, yang mengurangi ICP melalui vasokonstriksi vena serebral, telah digunakan pada versi awal konsep Lund untuk pasien dengan ICP yang tidak dapat dikendalikan. Dihidroergotamin tidak dipakai lagi karena kemungkinan adanya efek samping yang berhubungan vasokonstriksi perifer pada dosis tinggi. ${ }^{8-20}$

\section{Pedoman terapi COT Berat: Mana yang lebih baik?}

\section{Terapi ICP}

Evakuasi bedah yang segera untuk lesi massa intrakranial seperti hematoma dan lesi fokal (kadang-kadang dengan kombinasi dengan kraniektomi) dianjurkan untuk menurunkan ICP dan mengurangi efek buruk lainnya dari lesi. ${ }^{10}$

Bila CPP tinggi setelah trauma atau peningkatan dengan vasopresor, ada risiko bahwa lebih baiknya perfusi dan oksigenasi bersifat selintas pada pasien cedera dengan otak yang cedera dengan kapiler yang pasif permeabel terhadap solut kecil, dengan CPP yang tinggi akan meningkatkan tekanan hidrostatik kapiler dengan filtrasi transkapiler dan memperburuk edema vasogenik. Vasokonstriktor mungkin mempunyai efek samping ekstrakranial, seperti acute respiratory distress syndrome (ARDS), dan menyebabkan peningkatan kebocoran plasma, menyebabkan hipovolemia dan edema jaringan yang menyeluruh. Efek samping tipe ini dapat dikurangidenganmenerimaCPPyang lebihrendah daripada yang dianjurkan tahun 1996 dan tahun
2000 yaitu $70 \mathrm{mmHg}$, dan dengan menghindari penggunaan vasopresor. Pada BTF guideline 2007 dan 2016 CPP yang direkomendasikan adalah antara 50-70 $\mathrm{mmHg}$. Konsep Lund menganjurkan penggunaan terapi antihipertensi (beta-1 bloker, alpha-2 agonist, angiotensin-II antagonist). Hal ini telah ditunjukkan bahwa beta blokade pada COT berat memperbaiki survival dan alpha-2 agonist efektif efektif mengurangi tekanan darah pada COT berat dan berefek proteksi otak pada model invitro COT. Beta blokade juga mempunyai efek proteksi otal pada sitem kardiovaskular setelah COT. AngitensinII antagonist juga menguntungkan dengan menetralkan efek proinflamatori dari angiotensin. Juga menguntungkan untuk mencegah efek inflamatory dari noradrenalin. ${ }^{8-20}$ Dalam 10 tahun terakhir, telah diperkenalkan obat dan metode baru untuk pemantauan serebral, yang akan mempengaruhi pilihan kita, dalam memberikan anestesi pada pasien. Untuk pertimbangan outcome dari anestesi bedah saraf, obat dan alat pantau yang dipakai menjadi pertimbangan kita. Berdasarkan hal tersebut perlu melihat efek dari obat dan teknik terhadap perfusi otak dan metabolisme otak, untuk mempertimbangkan resiko terjadinya iskemia perioperatif. ${ }^{8-20}$ Hipotensi (tekanan sistolik $<90 \mathrm{mmHg}$ ) atau hipoksia $\mathrm{PaO}_{2}<60 \mathrm{mmHg}$, apnoe atau sianosis) harus betul-betul dihindari, dan segera dikoreksi. Tekanan arteri rerata harus dipertahankan $>90$ mmHg untuk mempertahankan tekanan perfusi otak $>70 \mathrm{mmHg} .{ }^{8-20}$

\section{Hipertensi atau Hipotensi?}

Tekanan perfusi otak harus dipertahankan minimum $70 \mathrm{mmHg}$. Tekanan perfusi otak yang didefinisikan sebagai MAP - tekanan intrakranial, sangat erat berhubungan dengan terjadinya iskemia serebral. Berdasarkan penelitian sebelumnya, adanya dokumen bukti nyata vasospasme pascatrauma dan ini jelas menunjukkan bahwa resistensi vaskuler berubah setelah trauma. Tekanan perfusi otak yang rendah mungkin membahayakan otak dengan preexisting iskemi dan memperbesar tekanan hidrostatik intravaskuler dengan meningkatkan tekanan perfusi otak, dapat menolong memperbaiki perfusi serebral. Dalam kebanyakan kasus, 
menaikkan tekanan perfusi otak dapat dilakukan dengan belbagai manipulasi klinis, sehingga tidak terjadinya iskemia global dan regional. ${ }^{8-20}$

\section{Mengapa perlu menaikkan Tekanan perfusi otak (CPP target)?}

Adanya peningkatan jumlah bukti-bukti bahwa aliran darah otak sangat rendah setelah cedera kepala dan pada banyak kasus hampir mendekati ambang iskemia. Rendahnya aliran darah otak ini mungkin disebabkan karena penekanan pembuluh darah serebral oleh massa intrakranial, penurunan metabolisme serebral pada pasien yang koma, serta adanya vasospasme pasca trauma (40\%). Pada suatu publikasi tahun 1992 menunjukkan bahwa outcome klinik lebih jelek pada pasien yang mengalami episode hipotensi sistolik $<90 \mathrm{mmHg}$ pada beberapa jam pertama atau hari setelah cedera. Suatu hubungan yang bertentanganadalah pada keadaan hipotensiterjadi kenaikan tekanan intrakranial pada bagian yang otoregulasinya masih baik. Ada suatu penelitian eksperimental bahwa suatu penurunan tekanan darah bertanggung jawab terhadap peningkatan tekanan intrakranial yang tiba-tiba, yang dapat dihilangkan bila tekanan darah dinaikkan lagi (Rosner, 1984). Juga ada bukti bahwa otoregulasi vasodilatasi sebagai respons terhadap hipotensi adalah kira-kira $65 \%$ dari diameter asal pembuluh darah. ${ }^{8-20}$ Karena itu sebagai simpulannya, mempertahankan tekanan perfusi otak $>70 \mathrm{mmHg}$ adalah suatu opsi terapi yang dapat menurunkan mortalitas dan memperbaiki kualitas pasien yang hidup dan memperbesar perfusi pada regio yang iskemik setelah cedera otak berat. Tidak ada satu penelitianpun yang menunjukkan bahwa hipertensi intrakranial, morbiditas, atau mortalitas meningkat bila secara aktif kita pertahankan tekanan perfusi otak diatas $70 \mathrm{mmHg}$, sekalipun ini berarti menormalkan volume intravaskuler atau dilakukan induce hipertensi sistemik. ${ }^{8-11}$

\section{Bagaimana dengan Terapi Konsep Lund?}

Konsep dari Lund untuk terapi edema otak telah diperkenalkan pada pada praktek klinis di Swedia. Pada pasien dengan cedera kepala berat tidak ada terapi farmakologi untuk memperbaiki BBB yang rusak atau memperbaiki otoregulasi yang terganggu. Terapi ini berdasarkan pada perkiraan bahwa edema otak ektraseluler yang disebabkan karena gangguan otoregulasi dan rusaknya barier darah-otak, merupakan suatu komponen penting pada pembengkakan otak pascatrauma dan lebih mudah dilakukan terapi daripada edema intraseluler. Tujuan tatalaksana adalah untuk mempertahankam tekanan intrakranial pada tingkatan yang aman sampai tercapainya perbaikan otoregulasi dan barier darah-otak untuk mencegah herniasi otak dan untuk mengurangi iskemia akibat cedera sekunder. Walaupun komponen Lund terapi adalah tindakan standar (menurunkan metabolisme otak, pengaturan glukosa dan suhu, penurunan volume darah otak dengan hiperventilasi atau barbiturat koma, mempertahankan tekanan koloid osmotik) penggunaan teknik hipotensi untuk menurunkan tekanan hidrostatik kapiler dengan tujuan untuk menurunkan edema serebral merupakan hal yang berlawanan dengan cara-cara konvensional dalam mempertahankan tekanan perfusi otak. ${ }^{8-11}$

\section{Mengapa penting untuk melakukan pengkajian konsep Lund?}

Meskipun ada perkembangan bukti riset COT, tidak semua aspek dari cedera otak sekunder dapat dimengerti dengan jelas. Sesuai dengan hal tersebut, konsep yang mendukung tatalaksana berbeda, antara target ICP dan target CPP. Konsep Lund menawarkan latar belakang teori yang menarik yang telah dikonfirmasikan dalam praktek. Hasil dari systematic review menyimpulkan bahwa tidak ada bukti randomized controll trial (RCT) dari efek konsep Lund dalam menangani COT berat. Tidak bukti dari penelitian RCT bahwa konsep Lund merupakan terapi yang lebih baik untuk cedera otak dan masih dibutuhkan riset selanjutnya.10 Konsep Lund menekankan untuk mengontrol perbedaan tekanan osmotik dan hidrostatik, sehingga memicu reabsorpsi transkapiler dari cairan interstitial. Hal ini dapat dilakukan dengan cara kombinasi farmakoterapi yang kompleks termasuk B1antagonist metoprolol, alpha2 agonist clonidine, tiopental dosisi rendah, dihidroergotamine, dan rumatan tekanan koloid osmotik dengan pemberian transfusi sel darah merah dan albumin. Walaupun perbaikan outcome dibandingkan 
Tabel 2. Aplikasi Klinis Konsep Gabungan untuk COT Berat

1. Evakuasi bedah dari hematoma dan kontusio. Pasang monitor ICP

2. Ventilasi mekanis untuk mencapai normal $\mathrm{PaCO}_{2}$ 35-39 mmHg dan $\mathrm{PaO}_{2}$ normal 90-105 mmHg. Gunakan PEEP 6-8 $\mathrm{cmH}_{2} \mathrm{O}$, intermiten bagging dengan pengaturan ICP, dan inhalasi untuk mencegah atelektasis. Kurangi dosis obat beta-stimulasi inhalasi (misalnya salbutamol) bila ada peningkatan ICP dan penurunan tekanan darah (vasodilatasi). Moderat hiperventilasi sebentar $(<2$ menit) dapat menghilangkan puncak ICP. Jangan diekstubasi sampai ICP stabil pada level normal.

3. Normotermi adalah optimal. Pada suhu tinggi yang menetap $\left(>38,5^{\circ} \mathrm{C}\right)$, suhu dapat diturunkan dengan paracetamol atau bolus solu-medrol intravena $5-10 \mathrm{mg} / \mathrm{kg}$. Hindari pendinginan secara aktip.

4. Nutrisi berikan energi rendah (15-20 kcal/kg/24 jam) untuk dewasa, untuk anak relatif lebih tinggi), berikan secara enteral. Pertahankan gula darah normal, bila perlu dengan insulin. Hindari hiponatremia.

5. Sedasi yang efektif dan pengurangan stres diperoleh dengan sedatif (midazolam, propofol, tiopental) dikombinasikan dengan alpha-2 agonist dan beta-1 blokade. Tiopental hanya digunakan dengan dosis rendah $(2-3 \mathrm{mg} / \mathrm{kg}$ bolis $+0,5-3 \mathrm{mg} / \mathrm{kg} / \mathrm{jam}$ intravena) untuk 2 hari untuk mencegah efek samping barbiturat (misalnya pneumonia, ARDS, demam).

6. Normovolemia diharuskan, dan dilakukan dengan infus eritrosit (darah yang sudah dikeluarkan leukositnya/leukocyte-depleted blood) untuk mencapai serum Hb normal (125-140 g/L) dan transfusi albumin untuk mencapai normal serum albumin (35-43 g/L), juga menormalkan tekanan onkotik plasma. Albumin direkomendasikan sebagai natural koloid dengan beberapa efek samping, dan lebih disukai dengan konsentrasi tinggi (20-25\%). Pengalaman menggunakan koloid sintetik pada pasien ini terlalu terbatas untuk dilakukan rekomendasi secara umum. Menghindari penggunaan kristaloid sebagai plasma ekspander. Terapi cairan ini mengurangi volume intersitial otak dan memperbaiki mikrosirkulasi. Diuretik dapat digunakan (bukan manitol). Kurangi penggunaan analog ADH pada poliuri.

7. ICP dapat dikendalikan dengan menormalkan tekanan onkotik plasma dan tekanan darah. Pengaturan tekanan darah dengan terapi anti hipertensif dan penurun katekholamine dengan beta-1 antagonist (misalnya metoprolol 0,04-0,08 mg/kg x 6-8 intravena).

CPP optimal bersifat individual, pada kebanyakan kasus 60-70 mmHg untuk dewasa, dan 40-55 mmHg bergantung pada umur untuk anak dan adolesen. CPP yang terlalu rendah dikoreksi dengan koreksi hipovolemia, tidak ada elevasi kepala berlebihan, hentikan tiopental, turunkan obat anti hipertensi. Jangan menggunakan vasopresor.

8. Elevasi kepala moderat (maksimum 20 derajat) dapat digunakan untuk mengurangi ICP, memberikan CPP yang dapat diterima. Penambahan elevasi kepala mengurangi venous return ke jantung.

9. Drainase CSF harus dihindari, tapi drainase melalui kateter ventrikular dapat digunakan bila ada ICP yang tinggi (critically high ICP). Drainase pada ICP yang tinggi dapat menolong mengendalikan ICP bila absorpsi CSF tidak adekuat.

10. Gelombang B-ICP yang lama atau ICP yang tinggi yang baru terjadi dan refleks Cushing dapat dihilangkan dengan dosis bolus dihidroergotamin (DHE) 3-4 ug/kg, 4 kali per hari selama 2 hari). DHE merupakan opsi terakhir sebelum kraniotomi.

11. Bila ICP meningkat dan mengancam nyawa walaupun sudah dlakukan tindakan-tindakan diatas, dilakukan unilateral atau bilateral dekompresi kraniektomi partial yang besar untuk mengurangi ICP, menghilangkan refleks Cushing dan mengurangi tekanan darah. Pengurangan ICP yang optimal dengan farmakologik dan terapi cairan (lihat point 1-9) harus diteruskan untuk mengurangi edema otak dan strangulasi pada sisi kraniotomi).

dengan hystorical control dan institusi lain telah dilaporkan dengan strategi-strategi berdasarkan konsep Lund dengan beberapa penelitian tidak acak/non random dari berbagai pusat neurologik Swedia, protokol tidak pernah kearah randomized control trial dan tidak pernah dievaluasi di luar Swedia. Tanpa menekankan efek iskemia serebral sekunder dan kontradiksi dengan terapi yang umum digunakan untuk optimisasi aliran darah otak dengan menambah CPP. Dalam kenyataannya, bukti yang baik berlawanan dengan penggunaan banyak komponen dari terapi Lund 
pada COT. Dengan tidak adanya bukti kuat untuk mendukungnya, konsep Lund tidak mungkin dapat menambah dukungan ditempat lain. ${ }^{11-12}$ Pada otak yang sehat, keseimbangan yang efektif antara tekanan osmotik dan tekanan hidrostatik transkapiler merupakan driving force untuk pertukaran cairan transkapiler. Permeabilitas yang rendah dari kombinasi sodium dan klorida dengan tekanan osmotik kristaloid yang tinggi (kira-kira $7500 \mathrm{mmHg}$ ) pada kedua sisi dari BBB meniadakan pertukaran cairan melalui BBB yang intact. Variasi tekanan darah sistemik umumnya tidak ditransmisikan pada kapiler-kapiler ini disebabkan tekanan hidrostatik intrakapiler serebral (dan aliran darah) dilindungi dengan autoregulasi. ${ }^{12-14}$

Pada COT, mungkin terjadi kerusakan BBB. Pertukaran air transkapiler ditentukan oleh perbedaan tekanan hidrostatik dan tekanan koloid osmotik antara kompartemen intrakapler dan ekstrakapiler. Autoregulasi aliran darah otak terganggu pada COT. Tekanan perfusi otak yang tinggi meningkatkan tekanan hidrostatik intrakapiler dan menyebabkan peningkatan air intraserebral dan meningkatkan ICP. ${ }^{14}$ Konsep Lund prinsipnya adalah mencegah pebentukan edema otak untuk mengurangi pergerakan air dari kapiler ke parenkhim otak dengan memelihara tekanan koloid osmotik kapiler dan mengurangi tekanan hidrostatik kapiler. Perbaikan mikrosirkulasi pada mikrosirkulasi serebral dengan menghindari vasokonstriksi. ${ }^{8,14}$ Pemeliharaan tekanan osmotik dengan albumin (dipertimbangkan kontraindikasi oleh beberapa SAFE trial subgrup analisis), produk darah, diuretik. Menurunkan tekanan hidrostatik dengan metoprolol, klonidin, tiopenton, dihidroergotamine (berefek vasokonstriksi prekapiler). ${ }^{8-14}$ Target CPP adalah bila ICP normal, targetnya $60-70 \mathrm{mmHg}$. Akan tetapi, bila ICP meningkat, maka target CPP adalah $50 \mathrm{mmHg}$. Pada penggunaan vasoaktif, harus dihindari dobutamine karena berefek vasodilatasi serebral dan hindari noradrenalin karena berefek vasokonstriksi serebral..$^{8-14}$ Konsep penggabungan dari ketiga target ini adalah suatu pendekatan alternatif untuk terapi cedera kepala berat. Hal ini didasari dari hipotesis berdasarkan pada prinsip fisiologik bertalian dengan pengendalian tekanan intrakranial, volume otak dan perfusi otak. Ini meliputi bagaimana tentang berbagai komponen seperti tekanan darah, ventilasi, nutrisi, sedasi, substitusi volume, dan suhu tubuh.

Prinsip konsep gabungan ini untuk tatalaksana cedera otak traumatik berat, dengan kombinasi sasaran utama yaitu 1) mengurangi ICP (ICPtargeted goal) dan 2) memperbaiki mikrosirkulasi pada daerah perikontusio (perfusion-targeted goal). Tujuan tatalasana adalah untuk menormalkan tekanan darah, tekanan onkotik plasma, volume plasma dan eritrosit, ventilasi, suhu tubuh dan elektrolit, penggunaan nutrisi enteral serta menghindari overnutrisi, vasopressor dan stres. Cara ini dapat dilakukan pada semua pasien dengan cedera otak traumatik, tanpa batasan umur, kapasitas autoregulatori, cedera traumatik lain atau multiple organ failure dan keterbatasan fasilitas rumah sakit. Tatalaksana ini harus segera dimulai untuk melawan kenaikan ICP dan cedera sekunder lainnya, sampai sejauh ini tidak ada efek samping dari tatalaksana. Tatalaksana juga menunjukkan keuntungan untuk organ lain dengan mencegah acute respiratory distress syndrome (ARDS) berat, iskemia intestinal, dan gagal ginjal. Akan tetapi, karena tidak ada bukti dari penelitian RCT bahwa konsep gabungan ini adalah tatalaksana yang lebih baik untuk COT berat, maka diperlukan penelitian lebih lanjut dalam skala yang lebih besar.

\section{Simpulan}

Ada tiga strategi konseptual yang dapat diterapkan pada tatalaksana fisiologis pasien cedera kepala berat di ICU bedah saraf. Setiap strategi memiliki tujuan fisiologis yang berbeda, didasarkan pada alasan untuk jaringan otak dan regulasi volume darah. Hal ini bergantung pada asumsi tertentu tentang status reaktivitas serebrovaskular dan integritas penghalang darah-otak. Sebagian besar algoritma tatalaksana yang digunakan dalam praktik klinis saat ini adalah gabungan dari ketiga konsep ini. Sayangnya, hanya ada beberapa protokol klinis yang menggabungkan pemahaman tentang patofisiologi cedera otak traumatik dari penelitian populasi, dengan interpretasi data 
pemantauan dari pasien secara individual, untuk memilih intervensi tataksana yang paling tepat. Tak satu pun dari algoritma tatalaksana yang saat ini digunakan di pusat-pusat neuroscience telah diuji dalam uji klinis acak yang menghasilkan hasil luaran pasti dan memuaskan. Hal ini menyebabkan terjadinya kontroversi tentang strategi yang diarahkan pada tujuan yang optimal untuk pasien cedera kepala berat. Pada akhirnya beberapa pusat neuroscience melakukan dan menyarankan untuk menggabungkan unsurunsur dari kedua pendekatan ICP dan CPP yang ditargetkan sebagai pedoman tatalaksana pasien dengan cedera otak traumatik berat di ICU. Hal terpenting utama pada kasus-kasus COT sebenarnya terletak pada pencegahan dari terjadi trauma itu sendiri, seperti peraturan-peraturan lalulintas dan edukasi para pengendara dan pengguna jalan yang terus berkembang, sehingga diharapkan angka kejadian kecelakaan lalulintas menurun. Hal terpenting kedua adalah pedoman tatalaksana transportasi pasien dengan COT, sehingga tidak terjadi cedera otak sekunder yang memperberat patofisiologi otak dan memperparah keadaan pasien saat tiba di rumah sakit. Hal-hal inilah yang diharapkan dapat meminimalisir hasil luaran pasien-pasien COT buruk.

\section{Daftar Pustaka}

1. Warner DS, Borel CO. Treatment of traumatic brain injury: one size does not fit all. Anesth Analg 2004;99:1208-10.

2. Muzevic D, Splavski B. The Lund concept for severe traumatic brain injury (review). Cochrane Database of Systematic Review 2013, Issue 12.

3. Helbok R, Meyfroidt G, Beer R. Intracranial pressure thresholds in severe traumatic brain injury: con. Intensive care med 2018;44:1318-20.

4. Zacchetti L, Magnoni S, Di Corte F, Zanier ER, Stocchetti N. Accuracy of intracranial pressure monitoring: systematic review and metaanalysis. Crit Care 2015; 19:420.
5. Brain Trauma Foundation, American Association of Neurological Surgeons, Congress of Neurological Surgeons. Guidelines for the management of severe traumatic brain injury. J Neurotrauma 2007;24(Suppl 1):S1-106.

6. Vik A, Nag T, Fredriksli OA, Skandsen $\mathrm{T}$, Moen KG, Schirmer-Mikalsen K, Manley GT. Relationship of "dose" of intracranial hypertension to outcome in severe traumatic brain injury. J Neurosurg.2008;109(4):678-84.

7. Carney N, Totten AM, O'Reilly C, Ullman JS, Hawryluk GW, Bell MJ. Guidelines for the management of severe traumatic brain injury, fourthedition. Neurosurgery2017;80(1):6-15.

8. Asgeirsson, B., Grände, P. O., and Nordström, C. H. A new therapy of post trauma brain oedema based on haemodynamic principles for brain volume regulation. Intensive Care Med 1994;20:260-67.

9. Olivecrona M. On severe traumatic brain injury. Edisi ke-1. Swedia: Department of Pharmacology and Clinical Neurosciences, Neurosurgery Umeå University 2008.

10. Dizdarevic K, Hamdan A, Omerhodzic I, Kominlija-Smajic E. Modified Lund concept versus cerebral perfusion pressure-targeted therapy: a randomized controlled study in patient with secondary brain ischemia. Clin Neurol Neurosurg 2012.

11. Koskinen LOD, Olivecrona M, Grande PO. Severe traumatic brain injury management and clinical outcome using the Lund Concept. Neuroscience 2014;283:245-55.

12. Bisri DY, Bisri T. Pengelolaan Perioperatif Cedera Otak Traumatik. Edisi ke-4. Bandung: Fakultas Kedokteran Universitas Padjadjaran, 2018.

13. Sharma D, Vavilala MS. Lund concept for the management of traumatic brain 
injury: a physiological principle awaiting stronger evidence. Journal of Neurosurgical Anesthesiology 2011;23(4):363-67.

14. Tempelhoff R. The Lund concept for management of traumatic brain injury. $\mathrm{J}$ of Neurosurgical Anesthesiology 2011;23(4):357.

15. Grande PO. The Lund Concept for the treatment of severe head trauma-physiological principles and clinical application. Intensive Care Medicine 2006, Issue: Aug 22.

16. Grande PO. Critical evaluation of the Lund Concept for treatment of severe traumatic head injury, 25 years after its introduction. Frontiers in Neurology 2017;8
17. Grande PO, Asgeirsson B, Nordstorm $\mathrm{CH}$. Volume-targeted therapy of increased intracranial pressure: the Lund concept unifies surgical and non-surgical treatment. Acta Anaesthesiol Scand. 2002.

18. Nordstorm $\mathrm{CH}$. The Lund concept: is this logical? Neurocrit Care 2005.

19. Nordstorm CH. Physiological and biochemical principles underlying volumetarget therapy-the "Lund concept". Neurocrit Care 2005.

20. GerberLM,ChiuYL.CarneyN,HartlR, GHajar $\mathrm{J}$. Marked reduction in mortality in patients with severe traumatic brain injury. Journal of Neurosurgery 2013; 119(6):1583-90. 